Między wykluczeniem a dobrobytem. Refleksja nad społeczną myśla encykliki „Centesimus annus” Jana Pawła II, red. B. Bąk,

R. Kantor, M. Kluz, J. Młyński, Kraków 2017, s. 149-165.

DOI: http://dx.doi.org/10.15633/9788374386289.07

Ks. dr hab. Robert Kantor

Wydział Teologiczny Sekcja w Tarnowie Uniwersytetu Papieskiego Jana Pawła II w Krakowie

\title{
Sprawiedliwość w ujęciu Javiera Hervady
}

\section{Wprowadzenie}

Istnienie prawa daje początek cnocie sprawiedliwości. Na temat sprawiedliwości od zarania dziejów wypowiadali się filozofowie, teologowie, a także prawnicy. Jednym z tych ostatnich jest wybitny kanonista hiszpański Javier Hervada.

Javier Hervada Xiberta urodził się 7 lutego 1934 roku w Barcelonie. Jest filozofem i teoretykiem prawa oraz kanonistą. Jako profesor filozofii prawa i prawa naturalnego wykłada na Wydziale Prawa Kanonicznego Uniwersytetu Navarry w Pampelunie od 1966 roku. Był dziekanem tego wydziału w latach 1973-1984. Założył czasopismo „Persona y Derecho” oraz był jednym z założycieli Instytutu Martín de Azpilcueta i czasopisma „Ius Canonicum”. Jest autorem wielu publikacji książkowych i artykułów z filozofii i prawa naturalnego ${ }^{1}$ oraz

1 Do najważniejszych publikacji należą: Introducción crítica al Derecho Natural, $10^{\text {a }}$ edición, $1^{\text {a }}$ reimpr., Pamplona 2007; Lecciones propedéuticas de Filosofía del 
prawa kanonicznego ${ }^{2}$. W roku 2002 otrzymał tytuł doktora honoris causa Papieskiego Uniwersytetu Świętego Krzyża w Rzymie.

Podejmując się omówienia tematu sprawiedliwości w ujęciu Javiera Hervady, trzeba mieć na uwadze, że jest on z przekonania zdecydowanym tomistą. Stąd też pojęcie czy definicję sprawiedliwości czerpie z myśli klasycznej. Fakt ten jest motywem odwołania się w niniejszym opracowaniu do filozofii greckiej, rzymskiej oraz myśli filozoficzno-teologicznej św. Tomasza z Akwinu. W artykule została zastosowana metoda systematyczna, której zwolennikiem jest prof. Hervada i która to metoda powinna uwypuklać realizm prawniczy.

\section{Rys historyczny klasycznej definicji sprawiedliwości}

Według prof. Hervady nie można podawać współczesnej definicji sprawiedliwości bez odniesienia się do źródeł i jej klasycznego rozumienia.

Derecho, 4a ed., Pamplona 2007; Cuatro lecciones de Derecho Natural, $4^{\text {a }}$ ed., Pamplona 1998; ¿Qué es el derecho? La moderna respuesta del realismo jurídico, Pamplona 2002; Historia de la Ciencia del Derecho Natural, Pamplona 1987 (3 ed. 1996); Escritos de Derecho Natural, Pamplona 1986 (2ª ed. 1993); Diálogos sobre el amor y el matrimonio, Pamplona 1974 (4a ed. 2007).

2 Najistotniejszymi publikacjiami w tym zakresie są: El Derecho del Pueblo de Dios, en colaboración con P. Lombardía, vol. I, Introducción. Derecho constitucional, Pamplona 1970; Elementos de Derecho Constitucional Canónico, Pamplona 1987 ( $2^{\text {a }}$ ed., 2001); Una caro. Escritos sobre el matrimonio, Pamplona 2000; Pensamientos de un canonista en la hora presente, Pamplona 1989 (reimpr. 1992; 2a ed., 2004); Vetera et Nova. Cuestiones de Derecho Canónico y afines (1958-2004), $2^{\text {a }}$ ed. remodelada, Pamplona 2005; El ordenamiento canónico. Aspectos centrales de la construcción del concepto, Pamplona 1966 ( $2^{\mathrm{a}}$ ed. 2008); Introducción al estudio del Derecho canónico, Pamplona 2007 (2 ed. 2010). 


\subsection{Grecja i Rzym}

Właściwe dzieje nauki prawa naturalnego otwiera filozofia grecka. W tradycji greckiej wyróżniamy najpierw okres mitologiczny, w którym sprawiedliwość i prawo zostały spersonifikowane jako boginie. Mit był sposobem na wyrażenie idei, że sprawiedliwość i prawo nie opierają się tylko na ustawach i przekonaniach ludzi, ale biorą początek z istniejącej uprzednio rzeczywistości. Na przełomie VII i VI wieku przed Chrystusem ideę sprawiedliwości oddawano za pomocą dwóch terminów: themis i dike. Pierwsze pojęcie odnosiło się do woli bogów, a drugie oznaczało logos, czyli rozum rządzący światem. Określenie themis znaczyło początkowo „coś ustanowionego jako reguła”, a następnie zaczęto nim określać także sprawiedliwość i prawo. Grecka polis, czyli organizacja polityczna ograniczona do miasta otoczonego murem, pozostająca pod ochroną swych bóstw opiekuńczych, podlegała tradycyjnym normom (themis) przekazywanym $\mathrm{z}$ ojca na syna jako reguły grupy plemiennej, na które składały się zasady moralne oraz przepisy prawa. Podstawą tych tradycyjnych norm była religia. Pod pojęciem themis rozumiano święte nakazy objawione monarchom przez bogów za pośrednictwem wyroczni. Dike, drugi termin odnoszący się do sprawiedliwości, także został spersonifikowany w osobie bogini o takim samym imieniu, córki Zeusa i Temidy. Dike z czasem zaczęło oznaczać rozum tkwiący we wszechświecie. Słowo to oprócz sprawiedliwości oznaczało także inne związane z nią zjawiska, takie jak kara, zemsta, naprawienie szkody. Nie oznaczało jednak - zdaniem Hervady - cnoty sprawiedliwości. Tę, jako cnotę moralną, nazywano dikaiosyne i rozumiano jako stosowanie lub praktykowanie porządku regulującego stosunki międzyludzkie ${ }^{3}$.

3 J. Hervada, La definición clásica de la justicia, w: In lustus ludex. Festgabe für Paul Wesemann zum 75. Geburtstag von seinen Freuden und Schülern, hrsg. K. Lüdicke, H. Mussinghoff, H. Schwendenwein, Essen 1990, s. 80. 
Jeden z największych filozofów greckich, Arystoteles, za to, co sprawiedliwe, uważał każdą rzecz przysługującą każdemu człowiekowi z osobna; tym, co sprawiedliwe $\mathrm{z}$ natury, była natomiast rzecz, która przysługuje ludziom $\mathrm{z}$ natury na podstawie naturalnej miary. Zdaniem Javiera Hervady Arystoteles ujął w skrócie teorię sprawiedliwości jako równości rzeczy podlegających wymianie i jako proporcji zachowywanej przy ich dystrybucji. Dokonał rozróżnienia pomiędzy sprawiedliwością $\mathrm{w}$ rozumieniu sędziego lub prawnika a sprawiedliwością $\mathrm{w}$ moralnym pojęciu czynienia dobra oraz życia według wszystkich cnót. To, co sprawiedliwe, to rzecz sprawiedliwa. Arystoteles odnosił się do porządku panującego w polis, w społeczeństwie, którego elementem jest cnotliwe życie obywateli. Sprawiedliwość to cnota skierowana ku innym, działająca na podstawie równości lub proporcji między dzielonymi, przypisywanymi lub wymienianymi rzeczami. I tak na przykład w umowie sprzedaży sprawiedliwość polega na równości lub adekwatności pomiędzy zapłaconą ceną oraz sprzedaną rzeczą; przy podziale obciążeń równość lub proporcja polega na tym, że ten, kto więcej posiada, przekazuje więcej do wspólnego majątku, a kto posiada mniej, dostarcza mniej. W tych wypadkach to, co sprawiedliwe, to cena, proporcjonalna część dóbr dostarczona przez kogoś, czyli rzecz, którą ktoś sprawiedliwie powinien dać lub otrzymać. To jest, jak twierdzi Hervada, to, co Rzymianie nazywali ius, czyli prawo. Prawo nie jest pierwotnie ustawą lub zdolnością moralną, ale rzeczą, czymś, co ktoś sprawiedliwie powinien otrzymać ${ }^{4}$.

Konkludując, należy stwierdzić, że dla Arystotelesa sprawiedliwość polega na tym, że podział dóbr w społeczeństwie powinien być sprawiedliwy, czyli równy lub proporcjonalny. Chodzi o to, by nikt nie otrzymał więcej, niż mu się należy, ani też mniej, niż mu przysługuje ${ }^{5}$.

4 J. Hervada, La definición clásica..., dz. cyt., s. 82.

5 "Sprawiedliwość jest więc tą cechą charakteru, dzięki której o człowieku sprawiedliwym mówi się, że zgodnie z postanowieniem postępuje sprawiedliwie; że 
Najbardziej znaną definicję sprawiedliwości u Rzymian podał Ulpian - rzymski prawnik: „Iustitia est constans et perpetua voluntas ius suum cuique tribuendi" 6 . Sprawiedliwość jest zatem stałą i ciągłą wolą dawania każdemu jego prawa ${ }^{7}$.

\section{2. Święty Tomasz z Akwinu}

Dla św. Tomasza z Akwinu sprawiedliwość jest zasadniczo cnotą ad alterum, odnosi się zawsze dla drugiego. Zdaniem Akwinaty sprawiedliwość jest stałą i wiekuistą wolą oddawania każdemu tego, co się mu należy. Skoro wszelka cnota to sprawność będąca zasadą dobrego postępowania, koniecznie trzeba określać cnotę ze względu na dobre postępowanie w zakresie właściwej dla niej materii.

mając dokonać jakiegoś podziału, czy to między siebie a kogoś innego, czy to między dwie inne osoby, nie przydziela sobie więcej rzeczy pożądania godnych (ani na odwrót, jeśli idzie o to, co szkodliwe), lecz przydzziela sobie to, co jest dla niego w stosunku do owej drugiej strony proporcjonalnie słuszne; a podobnie postępuje też, gdy idzie o podział między dwie inne osoby. I na odwrót: niesprawiedliwość jest tą trwałą dyspozycją, skutkiem której o człowieku niesprawiedliwym mówimy, że zgodnie z postanowieniem postępuje niesprawiedliwie. To zaś polega na nadmiernym i niedostatecznym przydzielaniu sobie i innym rzeczy pożytecznych lub szkodliwych, z pogwałceniem [właściwej] proporcji". Arystoteles, Etyka nikomachejska, tłum. D. Gromska Warszawa 2007, V, 5.

6 Ulpian, Digesta lustiniani Augusti, Mediolan 1960, 1, 1, 10.

7 “Con Ulpiano, la fórmula de la justicia, además de ganar en precisión, adquiere su más acabada dimensión jurídica, pues se matiza que lo suyo de cada uno es su derecho. Esto estaba contenido en «lo propio»y «lo justo» de Aristóteles, así como en el «mérito», que es algo debido en justicia; pero en Ulpiano se hace explícito. Sobre todo la fórmula de Ulpiano manifiesta mejor que las precedents un punto capital de la teoría de la justicia: la primacía del derecho sobre la justicia, o, dicho de otro modo, que la justicia está en función del derecho y no a la inversa; la justicia presupone el derecho. Si la justicia consiste en dar a cada uno su derecho, es obvio que para que se dé la acción justa - la propia de la justicia - es preciso que exista ese derecho, respecto del cual se es justo. Por eso Isidoro de Sevilla escribirá que: Iustus dictus quia iura custodit et secundum legem vivit". J. Hervada, La definición definición clásica de la justicia, w: tenże, Vetera et Nova..., dz. cyt., s. 639. 
„Właściwym tworzywem sprawiedliwości jest to, co się odnosi do drugich. Dlatego wyrażenie «oddawania każdemu, co się mu należy» wskazuje na czynności właściwe sprawiedliwości odnośnie do jej tworzywa i przedmiotu, gdyż ten jest sprawiedliwy, kto przestrzega prawa" ${ }^{8}$. Takie określenie sprawiedliwości na pierwszym miejscu wymienia wolę w celu wskazania, że jej czynność musi być dobrowolna. „Dodanie stałości i wiekuistości podkreśla niewzruszenie jej czynności” ${ }^{9}$. Sprawiedliwość odnosi się do czynności, ponieważ jest to sprawność w postępowaniu na podstawie sprawiedliwego wyboru. Święty Tomasz stwierdza, że sędzia, wydając wyroki oraz wskazania, oddaje każdemu, co się mu należy, ,jest jakby wcieleniem sprawiedliwości, a naczelnik państwa jest jej stróżem. Natomiast poddani oddają każdemu, co mu się należy, w sposób wykonawczy”.

Zdaniem św. Tomasza sprawiedliwość w swej treści wyraża stosunek do innych. Nie może być zatem sprawiedliwością to, co szkodzi społeczności, bo sprawiedliwość ma na celu dobro wspólne. „Rozdzielanie dóbr wspólnych pomiędzy wielu ludzi szkodzi wspólnemu dobru społeczności, bo prowadzi do wyczerpania wspólnych zasobów i demoralizuje ludzi. Przy rozdziale nie ma oddawania każdemu tego, co mu się należy, ale przywłaszczanie sobie tego, co przedtem było wspólne. A to nie jest zadaniem sprawiedliwości” ${ }^{10}$.

Javier Hervada stwierdza, że św. Tomasz z Akwinu zasadniczo przyjął koncepcję sprawiedliwości podaną przez Ulpiana. Dokonał w niej jednak pewnych doprecyzowann ${ }^{11}$. Według klasycznej koncepcji

8 Św. Tomasz z Akwinu, II-II, q. 58, a. 1.

9 Św. Tomasz z Akwinu, II-II, q. 58, a. 2.

10 Św. Tomasz z Akwinu, II-II, q. 61, a. 1.

11 „En cuanto a la descripción de la justicia, Tomás de Aquino acepta la de Ulpiano, aunque la somete a alguna precisión, lo que le lleva a presentar una definición matizada, que es técnicamente la más perfecta hasta ahora dada, aunque no sea la más conocida ni la más generalizada, que sigue siendo la romana. El matiz que introduce Tomás de Aquino es el siguiente: la fórmula ulpianea define la justicia por su acto, pues la voluntad perpetua y constante quiere decir el acto de voluntad, dotado de firmeza por el hábito en el que consiste la virtud; 
sprawiedliwość jest cnotą, która przynależy do sfery wolitywnej ${ }^{12}$. Sprawiedliwość to jedna z cnót kardynalnych lub moralnych, która może być naturalna albo nadprzyrodzona. Łaska wynosi ją do przestrzeni nadprzyrodzonej ${ }^{13}$. Sprawiedliwość jest cnotą moralną lub kardynalną, różną od cnót teologalnych (wiara, nadzieja, miłość). Nie można mieszać tych pojęć. Cnoty moralne to m.in. roztropność i sprawiedliwość. Mogą one uzyskać wsparcie łaski i przez to stać się cnotami nadprzyrodzonymi. W łonie Kościoła sprawiedliwość ma za swój przedmiot nie Boga - nie wierzyć, mieć nadzieję i kochać Boga ale wiernego, pasterza lub całą wspólnotę rozumianą jako respektującą prawa innych i wypełniającą swoje zobowiązania ${ }^{14}$.

siendo esto así, es más perfecto sustituir el acto por el hábito, ya que se trata de definir una virtud, que es un hábito. La definición tomista reformada reza así: iustitia est habitus secundum quem aliquis constanti et perpetua voluntate ius suum unicuique tribuit". J. Hervada, La definición clásica..., dz. cyt., s. 89.

12 „De lo visto hasta ahora se deduce, en primer lugar, que según la concepción clásica la justicia es una virtud, esto es, un hábito o disposición de una potencia humana, en este caso de la voluntad. El estatuto propio de la justicia es un estatuto volitivo - es algo que pertenece a la voluntad - no un estatuto intelectual; en otras palabras no es una idea o ideal, ni tampoco es un valor o juicio estimativo. La concepción de la justicia como idea o valor es algo ajeno al pensamiento clásico y sólo tiene sentido en el seno de una serie de corrientes de la filosofía moderna (kantianos, neokantianos, filosofía de los valores etc.), en las cuales la idea de virtud está trastocada. En una teoría de las virtudes, hacer de la virtud una idea o valor es un error. Y llamar valor a la justicia, aceptando la filosofía realista - la de Santo Tomás de Aquino - y su teoría de las virtudes, es una incongruencia". J. Hervada, La definición clásica..., dz. cyt., s. 90.

13 "La justicia es una de las cuatro virtudes cardinales o morales, que puede ser natural o sobrenatural, según esté o no enriquecida por la gracia. La graciaeleva la virtud de la justicia al plano sobrenatural, pero no cambia su naturaleza ni su objeto: la justicia sigue siendo la virtud de cumplir y satisfacer el derecho, dando a cada uno lo suyo. Por lo tanto, aunque se afirme que la justicia propia del Pueblo de Dios y del derecho canónico es la justicia sobrenatural, ésta sigue siendo la virtud de cumplir y satisfacer el derecho". J. Hervada, La definición clásica..., dz. cyt., s. 90.

14 „La justicia es una virtud moral o cardinal, distinta de las virtudes teologales (fe, esperanza y caridad). En la teoría de las virtudes no se pueden confundir las virtudes morales con las virtudes teologales. Las virtudes morales son la prudencia, la justicia, la fortaleza y la templanza. Estas virtudes pueden recibir la 


\section{Sprawiedliwość jako zapewnienie każdemu tego, co do niego należy}

$\mathrm{Na}$ fundamencie tomistycznej definicji sprawiedliwości Javier Hervada oparł swoje przemyślenia w tej materii. Otóż zdaniem profesora z Pampeluny aby dobrze zrozumieć sprawiedliwość, należy mieć na uwadze podstawową zasadę: sprawiedliwość jest następstwem prawa. Akt sprawiedliwości nie może zaistnieć tam, gdzie nie ma tytułu do rzeczy, gdzie rzecz nie jest czymś należnym, czyli prawem. Sprawiedliwość działa, gdy prawo już powstało, przyznając każdemu to, co do niego należy ${ }^{15}$. W tym kontekście Hervada stawia pytanie: Jak zatem mówić o prawie sprawiedliwym i niesprawiedliwym? Pytanie to pojawia się w kontekście prawa pozytywnego. Możliwość powstania takiego problemu oznacza zdaniem Hervady, że stanowienie prawa pozytywnego odbywa się w kontekście jakiegoś prawa je

ayuda de la gracia y ser virtudes sobrenaturales, pero se distinguen claramente de las virtudes teologales, que tienen por objeto directo a Dios. En el seno de la Iglesia, la justicia no tiene por objeto directo a Dios - creer, esperar y amar a Dios - sino al fiel, al pastor o a la comunidad entera, en cuanto consiste en respetar los derechos de los demás y en cumplir fielmente las leyes. Afirmar que la justicia eclesial consiste en la vivencia de las virtudes teologales, supone un error, cuyo origen está en la negación de que exista derecho en la Iglesia y, por consiguiente, en la desaparición de la justicia como virtud de las relaciones intersubjetivas eclesiales. En efecto, la justicia como virtud de dar a cada uno su derecho depende de la existencia del derecho; allí donde hay derecho, por la propia naturaleza de éste, es obligado satisfacerlo y cumplirlo, lo cual es precisamente la justicia. La justicia como virtud del ius suum cuique tribuendi es una consecuencia necesaria del derecho. Pero si éste no existe, entonces tal justicia tampoco existe. En virtud de esa conexión necesaria entre justicia y derecho, si se dice que en la Iglesia la justicia no es la virtud cardinal - la del ius suum cuique tribuere - sino que ésta no existe porque se confunde con las virtudes teologales, tal afirmación no es coherente ni aceptable si no se parte de que el derecho en sentido propio no existe en la Iglesia. Esta inexistencia del derecho en sentido propio -sustituido por una realidad meramente analógica - es tesis explícitamente mantenida por quienes sustituyen la verdadera justicia por la vivencia de las virtudes teologales, lo cual es prueba patente de su ajuridismo". J. Hervada, La definición clásica..., dz. cyt., s. 90-91.

15 J. Hervada, Introducción crítica al Derecho Natural, Pamplona 1994, s. 27. 
poprzedzającego, prawa samego w sobie, które nazywa naturalnym. Prawo pozytywne może zapewnić komuś to, co do niego należy, lub odmówić mu tego, a przez to stać się albo prawem sprawiedliwym, albo niesprawiedliwym. Tym, co poprzedza prawo pozytywne, jest nie sprawiedliwość, a prawo naturalne. „Jeśli założyłoby się, że poza prawem pozytywnym nie ma żadnego autentycznego istniejącego uprzednio prawa, nie mogłaby pojawić się kwestia prawa niesprawiedliwego w ścisłym tego słowa znaczeniu"16.

\subsection{Rzeczy są rozdzielane}

Zdaniem prof. Hervady punkt wyjścia sprawiedliwości stanowi zawsze okoliczność, że „rzeczy zostały rozdzielone”, nie zaś, że „należy dzielić rzeczy” - poza jednym przypadkiem, czyli podziałem wtórnym, kiedy to rzeczy zostały już, w taki czy inny sposób, uprzednio rozdzielone lub przydzielone. Imperatyw "należy rozdzielać rzeczy” albo „rzeczy należy dzielić dobrze czy też lepiej” w odniesieniu do podziału pierwotnego, czyli innymi słowy, wobec braku istniejącego uprzednio, prawdziwego i właściwego prawa, nie jest nakazem natury prawnej, lecz moralnej. Uprzednie istnienie prawa jest cechą wyróżniającą sprawiedliwość. Przykładowo, jeżeli przedstawiciele pracowników i przedsiębiorców zasiądą przy stole, by negocjować wysokość wynagrodzeń - czyli by ustalić, jaka część zysku przedsiębiorstwa powinna się znaleźć w rękach strony pracowniczej - jest to zasadniczo kwestia polityki pracowniczej. Natomiast rzeczywista dystrybucja tego zysku przeprowadzona na podstawie uzgodnień (wypłata ustalonych wynagrodzeń) - stanowi akt sprawiedliwości; dokonuje się uzgodnionego podziału, realizuje się podział już dokonany

16 „Si se entendiese que, fuera del derecho positivo, no hay ningún verdadero derecho preexistente, no cabría plantear el tema del derecho injusto en propio sentido". J. Hervada, Introducción crítica..., dz. cyt., s. 27. 
w porozumieniu powstałym na drodze negocjacji. Temu przedstawionemu przykładowi można zarzucić, że podział podlegający negocjacjom nie stanowi jedynie zagadnienia polityki pracowniczej, ale także sprawiedliwości. Uzgodnione wynagrodzenie może być sprawiedliwe bądź niesprawiedliwe. Mało tego, całe doniosłe zagadnienie słusznej płacy powstało, ponieważ w licznych przypadkach wynagrodzenia były i są niesprawiedliwe, mimo że zostały zaakceptowane przez osobę zatrudnioną na podstawie umowy o pracę. Dlatego też $\mathrm{w}$ proces negocjacji w sprawie wynagrodzeń może zostać wpleciona kwestia sprawiedliwości. Tak samo może się zdarzyć, że system dokonywania przydziału jest niesprawiedliwy - przykładem może być podział własności w niektórych krajach. Jeżeli dany system prawa stanowionego jest niesprawiedliwy, oznacza to, że nie jest zgodny z prawem naturalnym. Tylko wówczas zachodzi autentyczna niesprawiedliwość, jeśli dokonano podziału między pracę i kapitał ${ }^{17}$.

Idąc dalej, Hervada stwierdza, że oprócz tego, że „rzeczy są rozdzielane”, nie mniejsze znaczenie ma teza, że „rzeczy każdej osoby rzeczy czyjeś - znajdują się, lub, w określonym momencie, mogą znaleźć się, we władaniu kogoś innego". Aby nastąpił akt sprawiedliwości, konieczne jest, by czyjaś rzecz znalazła się (lub mogła się znaleźć) - we władaniu innej osoby; tylko wtedy ten drugi będzie mógł zapewnić wydać lub uszanować - to, co należy się temu pierwszemu. Jedynie tak można zapewnić komuś to, co do niego należy. Z innego punktu widzenia zjawiskiem odmiennym, ale o podobnych skutkach, dotyczącym zajmującego nas przypadku, jest niesprawiedliwość, czyli okoliczność, w której ktoś uszkadza albo przywłaszcza sobie bezprawnie rzecz innej osoby; wówczas aktem sprawiedliwości - czynnością dążącą do zagwarantowania tego, co do kogoś należy - będzie przywrócenie stanu poprzedniego lub naprawienie szkody ${ }^{18}$.

17 J. Hervada, Introducción crítica..., dz. cyt., s. 28.

18 J. Hervada, Introducción crítica..., dz. cyt., s. 30-31. 


\subsection{Formuła sprawiedliwości, czyli zagwarantować każdemu to, co do niego należy}

Na tym tle Hervada definiuje formułę sprawiedliwości: „zagwarantować każdemu to, co do niego należy".

\section{Zagwarantować (zapewnić)...}

Najpierw należy odpowiedzieć na pytania: co to znaczy zagwarantować? Czy odnosi się to do czynności czy do normy? "Zagwarantować” oznacza każde działanie lub zaniechanie, na mocy którego rzecz przechodzi w rzeczywiste władanie tego, komu władztwo nad nią prawowicie przysługuje, tj. na podstawie tytułu prawnego (umowa, ustawa, zwyczaj, natura itd.) Odpowiadając na drugie pytanie, w odniesieniu do sprawiedliwości - zdaniem Hervady - należy wyróżnić trzy kwestie: cnotę, nakaz oraz rzecz należną (rzecz sprawiedliwą). Cnota sprawiedliwości jest stałą skłonnością woli, nakaz to ustawa lub norma, a to, co sprawiedliwe, to rzecz (rzecz należna). Zatem obowiązek zagwarantowania nie tkwi w pierwszej kolejności w sprawiedliwości, ale w rzeczy sprawiedliwej (w tym, co należne), ponieważ stanowi dług wobec kogoś.

Spotykamy się tu ze szczególnym przypadkiem tego, co w moralności jest uniwersalne. Chodzi mianowicie o relacje między cnotą a ustawą lub przepisem. Cnoty polegają na gotowości do przestrzegania prawa, tego, do czego jest się zobowiązanym. Jeśli powiem, że cnoty zobowiązują, i mam na myśli obowiązek sprawiedliwości, umiarkowania, męstwa itd., to nie chcę przez to powiedzieć, że są to normy czy przepisy. Każda z cnót to nawyk lub skłonność, nic innego; jednakże jest to skłonność do przestrzegania prawa, naturalnego czy też pozytywnego. Dlatego rdzeniem moralności nie jest cnota - jak twierdzą niektórzy - lecz prawo (lex), choćbyśmy za prawa podstawowe uważali wymagania 
wynikające $\mathrm{z}$ istoty człowieczeństwa. Cnota podporządkowana jest obowiązkowi, nie odwrotnie. Obowiązek sprawiedliwości to wyrażenie oznaczające prawo, wymóg czy też obowiązek, którego spełnienie stanowi akt sprawiedliwości, innymi słowy, to prawo o charakterze wiążącym - naturalne lub pozytywne. Dla cnoty sprawiedliwości obowiązek powstaje dlatego, że czyjaś rzecz, którą się gwarantuje, jest długiem, czymś należnym; to nie cnota sprawiedliwości czyni go należnym ${ }^{19}$.

Skoro prawo istnieje przed sprawiedliwością, w jaki sposób da się stwierdzić, że prawo pozytywne jest sprawiedliwe lub niesprawiedliwe? Sprawiedliwość lub jej brak stwierdza się w odniesieniu do istniejącego wcześniej prawa, a taka teza dotyczy zapewniania lub niezapewniania komuś tego, co mu się należy. Dlatego prawo pozytywne może być sprawiedliwe lub niesprawiedliwe w nawiązaniu do prawa, które istniało uprzednio, do prawa naturalnego. Sprawiedliwość prawa pozytywnego wiąże się z prawem naturalnym. Niedostosowanie prawa pozytywnego do wartości lub postulatów etycznych i społecznych zawsze będzie problemem prawa błędnego lub niemoralnego. Jeżeli nie istnieje właściwe i autentyczne prawo poprzedzające prawo pozytywne, nie można mówić o prawie niesprawiedliwym we właściwym i ścisłym sensie. Na tym polega tragedia pozytywizmu prawniczego; negacja prawa naturalnego pozostawia bez treści kwestie prawa niesprawiedliwego, ponieważ niedopuszczalna jest hipoteza, że prawo może być niesprawiedliwe ${ }^{20}$. Skoro sprawiedliwość to skłonność do przestrzegania prawa, a w założeniach pozytywistycznych występuje jedynie prawo pozytywne, nie ma innej sprawiedliwości poza zgodnością z prawem pozytywnym. Zatem przestrzeganie prawa - jakie by ono nie było - jest sprawiedliwe. Zdaniem Hervady

19 J. Hervada, Introducción crítica..., dz. cyt., s. 33.

20 J. Hervada, Introducción crítica..., dz. cyt., s. 34. 
można co najwyżej mówić o prawie błędnym, które jest sprzeczne z powszechną i uniwersalną opinią ludzkości. Jeśli pozytywista rozprawia o sprawiedliwości, zmienia najpierw jej definicję. Nie brzmi już ona: „zagwarantować każdemu to, co do niego należy”. Taki zabieg pozbawia człowieka czegoś jemu właściwego, z wyjątkiem tego, co przyznaje mu prawo pozytywne ${ }^{21}$.

\section{...każdemu...}

Określenie „każdemu” jest bardzo precyzyjne. Sprawiedliwość polega nie na tym, by zapewniać rzeczy ludzkości, klasie robotniczej, narodowej czy ludowi, nie odnosi się do praw kobiet, rasy czarnej, wykluczonych ani dziecka. Sprawiedliwość jest skierowana do każdego, gdyż dotyczy wszystkich i każdej z osobna osoby fizycznej lub prawnej, którym przysługuje tytuł do czegoś. Sprawiedliwość zapewnia to, co się należy każdemu uprawnionemu, człowiekowi, kobiecie, dziecku itd. Stwierdzenie, że prawo gwarantuje się każdemu, oznacza, że cnocie sprawiedliwości obce są dyskryminacja czy subiektywizm. Mówi o tym Pismo Święte: „Nie będziecie wydawać niesprawiedliwych wyroków. Nie będziesz stronniczym na korzyść ubogiego ani nie będziesz miał względów dla bogatego. Sprawiedliwie będziesz sądził bliźniego" (Kpł 19, 15).

Zasada niedyskryminacji nie oznacza, że należy „zagwarantować każdemu to samo”, gdyż formuła sprawiedliwości brzmi: „zagwarantować każdemu to, co mu się należy". Istnieją rzeczy, które przysługują w równej mierze wszystkim - uniwersalne, naturalne prawa człowieka - gdyż znajdują uzasadnienie w tym, że wszyscy ludzie są równi. Są jednak rzeczy rozdzielane w zróżnicowany sposób i wskutek tego nie należą jednakowo do wszystkich ${ }^{22}$.

21 J. Hervada, Introducción crítica..., dz. cyt., s. 35.

22 J. Hervada, Introducción crítica..., dz. cyt., s. 36-37. 


\section{- ...to, co do niego należy}

To, co jest należne, to rzecz. Rzecz może oznaczać dobra lub dolegliwości (np. karę za przestępstwo), coś materialnego lub niematerialnego (np. dobrą opinię lub stanowisko), może odnosić się do osoby (np. do dziecka), działalności ludzkiej (np. pracy, sprawowania urzędu), może to być jedno lub kilka zwierząt. Zatem w odnośnym terminie zawiera się wszystko to, co człowiek może nazwać „swoim” lub „czyimś” 23.

Sprawiedliwość może działać jedynie w stosunkach między ludźmi i dlatego jej przedmiot powinien charakteryzować się uzewnętrznieniem. Uzewnętrznienie oznacza, że rzecz, w taki czy inny sposób, znajduje się poza danym podmiotem i dlatego stanowi potencjalny przedmiot stosunków między ludźmi. Jest to kluczowe dla sprawiedliwości, gdyż jej akt opiera się na tym, że tytuł do rzeczy, jej posiadania czy korzystania z niej mogą zostać zakłócone lub znaleźć się we władaniu innej osoby niż ta, której przysługują ${ }^{24}$.

\subsection{To, co sprawiedliwe}

Język potoczny nadaje stwierdzeniu „to, co sprawiedliwe” sens ogólny, zgodnie z którym sprawiedliwe jest wszystko to, co odpowiada sprawiedliwości. Zdaniem Hervady podobnie jak „sprawiedliwość” przyjmuje w sztuce prawniczej bardzo ścisłe znaczenie, „to, co sprawiedliwe", jest równie precyzyjne w stosunku do sztuki prawa. To, co sprawiedliwe, jest tożsame z tym, co należne, dlatego jest rzeczą albo zbiorem rzeczy. Sprawiedliwość definiowana jako cnota gwarantowania każdemu jego prawa nie może być uważana za cnotę przyznania 
każdemu jego prawa podmiotowego. Rzecz przyznana komuś na podstawie jakiegokolwiek tytułu nazywa się prawem (ius) ze względu na właściwość, która umiejscawia ją w sferze prawnej. Coś jest sprawiedliwe, ponieważ jest prawem, a nie odwrotnie ${ }^{25}$.

To, co sprawiedliwe, jest rzeczą, która sprawiedliwie przysługuje innej osobie i wskutek tego należy mu ją zapewnić ${ }^{26}$. To, co sprawiedliwe, jest dokładnie tym, co się należy. Kto daje mniej, nie daje drugiemu tego, co do niego należy, czegoś, co mu przysługuje. Kto daje więcej, daje coś, co nie jest drugiemu należne. Równość właściwa dla tego, co sprawiedliwe, to równość w znaczeniu ogólnym, którą - zdaniem prof. Javiera Hervady - można rozumieć na trzy sposoby: jako tożsamość, równowartość i proporcjonalność.

- Tożsamość zachodzi, kiedy należy zagwarantować coś, co stanowi dokładnie te samą rzecz, która wyszła ze sfery władania podmiotu, któremu się ją przypisuje. Przykładowo, jeżeli ktoś pożyczył samochód, powinien zwrócić dokładnie ten sam samochód; rodzice powinni wychowywać i kształcić swoje dziecko, nie zaś innego młodego człowieka o podobnych cechach.

25 J. Hervada, Introducción crítica..., dz. cyt., s. 42.

26 Mamy to wyraźne odniesienie do klasycznej koncepcji sprawiedliwości. Sprawiedliwość we właściwym tego słowa znaczeniu jest cnotą odnoszącą się do relacji z drugimi. Nie chodzi tu o relację człowieka z Bogiem, ale relacje między osobami. Hervada stwierdza: „La justicia en sentido propio y estricto es una virtud de las relaciones entre hombres. No se refiere a las relaciones del hombre con Dios. Aunque a lo largo de la historia se ha llamado justicia a la virtud general y, en el lenguaje bíblico, a la santidad, la justicia en sentido propio es una virtud particular, que se refiere a las relaciones humanas. Dentro de las relaciones humanas, la justicia se refiere a las relaciones de derecho y surge allí donde hay derecho. Por lo tanto, si en la Iglesia hay derecho, en las relaciones intersubjetivas eclesiales tiene vigencia la justicia, como virtud de cumplir y satisfacer el derecho. Esta justicia eclesial no se refiere a las relaciones del hombre con Dios, ni a las de Dios con los hombres, sino a las relaciones de los fieles y pastores entre sí (justicia conmutativa y justicia distributiva) y a la relación de las personas con la comunidad eclesiástica (cumplimiento de las leyes jurídicas - divinas y humanas - o justicia legal). J. Hervada, La definición clásica..., dz. cyt., s. 90. 
- Stosunek równowartości zachodzi, gdy rzecz, którą należy zagwarantować, jest równa pod względem ilości i jakości rzeczy, która wyszła ze sfery władania podmiotu, któremu się ja przypisuje. Jeżeli np. pożyczono pieniądze znajdujące się w obrocie, to oczywiście zwrotowi podlegają nie te same banknoty lub monety, ale ta sama ich ilość, czyli ta sama wartość.

- Proporcja, czyli równość proporcjonalna. W podziałach, czyli nadaniach, należność ustala się według celu podziału i według stosunku między uczestniczącymi w nim podmiotami a owym celem. Na przykład równość w traktowaniu chorych nie polega na podaniu wszystkim tych samych leków, ale na zapewnieniu każdemu tego leku, którego potrzebuje ${ }^{27}$.

\section{Konkluzje}

Zagadnienie sprawiedliwości w ujęciu Javiera Hervady można sprowadzić do kilku tez:

1) Profesor z Pampeluny wychodzi od klasycznej definicji sprawiedliwości, którą św. Tomasz z Akwinu zdefiniował jako stałą i wiekuistą wolę oddawania każdemu tego, co się mu należy.

2) Sprawiedliwość to jedna z cnót kardynalnych lub moralnych, która może być naturalna albo nadprzyrodzona. Łaska wynosi cnotę sprawiedliwości do przestrzeni nadprzyrodzonej.

3) Sprawiedliwość we właściwym tego słowa znaczeniu jest cnotą odnoszącą się do relacji z drugimi. Nie chodzi tu o relację człowieka z Bogiem, ale relacje między osobami.

4) Rdzeniem moralności nie jest cnota, lecz prawo (lex), nawet jeżeli uważać za prawa podstawowe wymagania wynikające $\mathrm{z}$ istoty człowieczeństwa. Cnota podporządkowana jest obowiązkowi, nie

27 J. Hervada, Introducción crítica..., dz. cyt., s. 47-48. 
odwrotnie. Obowiązek sprawiedliwości to wyrażenie oznaczające prawo, wymóg czy też obowiązek, którego spełnienie stanowi akt sprawiedliwości.

5) Sprawiedliwość lub jej brak stwierdza się w odniesieniu do istniejącego wcześniej prawa, gdyż takie stwierdzenie dotyczy zapewniania lub niezapewniania komuś tego, co mu się należy.

6) Sprawiedliwość jest następstwem prawa. Akt sprawiedliwości nie może zaistnieć tam, gdzie nie ma tytułu do rzeczy, gdzie rzecz nie jest czymś należnym, czyli prawem. Sprawiedliwość działa, gdy prawo już powstało, przyznając każdemu to, co do niego należy. 
- 